\title{
Natural monoclonal antibody to oxidized low-density lipoprotein and Aggregatibacter
} actinomycetemcomitans

\author{
Chunguang Wang ${ }^{1,2}$ * and Sohvi Hörkkö ${ }^{1,2}$
}

${ }^{1}$ Medical Microbiology and Immunology, Research Unit of Biomedicine, Faculty of Medicine, University of Oulu, Oulu 90014, Finland.

${ }^{2}$ Medical Research Center and Nordlab Oulu, University Hospital and University of Oulu, Oulu 90029, Finland

*Correspondence to: Chunguang Wang, Medical Microbiology and Immunology, Research Unit of Biomedicine, Faculty of Medicine, University of Oulu, Oulu 90014, Finland. Phone: +358-294-485891; Fax: +358-294-485908; E-mail: chunguang.wang@oulu.fi

Running Head: Natural monoclonal antibody to oxLDL and $A a$ chaperonin 60 


\begin{abstract}
Natural antibodies are produced by B lymphocytes without exogenous antigenic exposure and are present at the time of birth. They are usually binding to conserved epitopes on antigens of different chemical composition. We cloned and characterized a natural mouse monoclonal IgM antibody (Aa_Mab) by selecting the binding to malondialdehyde acetaldehyde (MAA) adducts on low density lipoprotein (LDL). The data showed that the Aa_Mab cross-reacted with Aggregatibacter actinomycetemcomitans $(A a)$ bacteria, an important oral pathogen in periodontitis associated with atherosclerosis. Surprisingly, the binding molecule of $A a$ bacteria to the Aa_Mab was Aa chaperonin 60 or HSP60, a protein which is not only responsible for maintaining cellular proteins conformation, but also functions as a potent virulence factor prompting bone resorption in periodontitis and as a putative pathogenic factor in atherosclerosis.
\end{abstract}

Key words: Natural antibody, oxidized low density lipoprotein, malondialdehyde acetaldehyde, Aggregatibacter actinomycetemcomitans, chaperonin 60 


\section{Introduction}

The innate immune response is important for the host's first line defence against various pathogens and tissue injury. Natural antibodies are an essential part of innate immune system, they arise without exogenous antigenic stimulation and are present at birth [1]. Natural antibodies are produced T-cell independently by B1 B-lymphocytes, marginal zone B-cells and other B cell types, and include all immunoglobulin isotypes [1-3]. The role of natural antibodies is to protect against microbial antigens and to serve as innate recognition receptors for homeostatic housekeeping functions and removal of altered self-antigens [1, 4, 5]. Approximately one third of natural IgM isotype of antibodies in mice have been proposed to bind to oxidation specific epitopes found in atherosclerotic plaques, such as malondialdehyde adducts (MDA -adducts), and therefore natural IgM antibodies have been focus of studies in atherosclerotic cardiovascular diseases. Mice lacking both secretory $\operatorname{IgM}\left(\mathrm{sIgM}^{--}\right)$and $\operatorname{low}-$ density lipoprotein receptor $\left(\mathrm{LDLR}^{-/}\right)$have been shown to have more progressive atherosclerosis [6], suggesting a protective role of IgM isotype of antibodies. Also, and mice lacking apolipoprotein $\mathrm{E}\left(\mathrm{ApoE}^{--}\right)$and spleen (splenectomized) showed reduced atherosclerosis and increased plasma IgM levels when adoptively transferred with B1a cells [7], suggesting that IgM secreted by B1a lymphocytes is atheroprotective. In humans, plasma levels of IgM binding to MDA modified low-density lipoprotein, MDA-LDL, are inversely associated with surrogate markers of atherosclerosis [8,9], and new born babies have monoclonal IgM to malondialdehyde acetaldehyde modified low density lipoprotein (MAALDL) displaying similar properties with the monoclonal mouse natural IgM linked to atheroprotection [10]. Malondialdehyde acetaldehyde is the immunodominant epitope in MDA-LDL and natural IgM to MAA-adducts in mice have been documented to cross-react 
with bacterial epitopes in Porphyromonas gingivalis [11] and Aggregatibacter actinomycetemcomitans [12].

$P$. gingivalis $(\mathrm{Pg})$ and $\mathrm{A}$. actinomycetemcomitans $(\mathrm{Aa})$ are gram-negative rod bacteria considered as the most important pathogens causing periodontitis, an inflammatory disease leading to loss of tooth-supportive tissue. Periodontitis is well established to be associated with atherosclerotic cardiovascular disease $[13,14]$, and it has been proposed that activation of the immune system by P.gingivalis and A.actinomycetemcomitans bacteria may be contributing factors [14-18]. Gingipain, a protease secreted by P.gingivalis, has been shown to share molecular identity with epitopes on MDA-LDL, and immunization with MDA-LDL moderates atherosclerosis in $\operatorname{LDLR}^{-/-}$mice challenged with live P.gingivalis $[11,19]$. Yet, the causal relationship and pathological mechanism have remained elusive.

Here a natural mouse monoclonal IgM (Aa_Mab) was selected by screening the IgM binding of hybridoma cell culture media to MAA-epitope on LDL. The hybridoma cell line had been generated from splenocytes of a non-immunized nrf $2^{-/-}$mouse by fusion with mouse myeloma cell line. The binding of the purified Aa_Mab was screened to models of oxidized LDL and different bacteria including to several serotypes of $A$. acinomycetemcomitans using chemiluminescence immunoassay, Dot blot, and Western blot. The monoclonal IgM antibody (Aa_Mab) was produced by growing the cell line in serum-free HyClone ${ }^{\mathrm{TM}}$ SFM4Mab-Utility media and purifying the culture media with Superose 6 10/30 GL high-performance size exclusion chromatography. The sequence analyses of the variable heavy $\left(\mathrm{V}_{\mathrm{H}}\right)$ and variable light kappa $\left(\mathrm{V}_{\mathrm{k}}\right)$ chains were attained by amplifying cDNAs reversely transcribed from hybridoma total RNA. Mass spectrometry analysis revealed that the epitope in $A$. acinomycetemcomitans recognized by the monoclonal Aa_Mab IgM was chaperonin 60, i.e. 
heat shock protein 60 , a powerful virulence factor of the bacteria and also a known risk factor associated with atherosclerosis. The binding characteristics of the Aa_Mab IgM to A. acinomycetemcomitans chaperonin 60 was further demonstrated by using purified recombinant $A a$ chaperonin 60 expressed in BL21(DE3) Escherichia coli cells. 


\section{Materials}

\subsection{Bacteria and Hybridoma Cells}

1. A.actinomycetemcomitans strains (ATCC 29523, ATCC 43718, ATCC 33384, IDH 781, IDH 1705, CU1000, C59A, representing 6 serotypes $a, b, c, d, e, f$ and one nonserotypeable strain $x$ ) [20], E. coli and Streptococcus pyogenes (control strains).

2. Fastidious anaerobic agar (FAA) plates.

3. Dulbecco's phosphate buffered saline $(10 \times \mathrm{PBS})$ : the working solution is made by $1: 10$ dilution in water $(1 \times \mathrm{PBS})$.

4. $D C^{\mathrm{TM}}$ (detergent compatible) protein assay kit.

5. $\mathrm{CO}_{2}$ incubator.

6. Splenocytes from a non-immunized nrf $2^{-/-}$mouse and P3×63Ag8.653.1 myeloma cells.

7. Serum-free Dulbecco's Modified Eagle's Medium (DMEM).

8. 20\% FBS-DMEM: DMEM, 20\% fetal bovine serum (FBS), $10 \mathrm{mM}$ 4-(2-hydroxyethyl)1-piperazineethanesulfonic acid (HEPES), $0.1 \mathrm{mM}$ non-essential amino acids (NEAA), $100 \mathrm{U} / \mathrm{mL}$ penicillin, $100 \mu \mathrm{g} / \mathrm{mL}$ streptomycin, $50 \mu \mathrm{M} \beta$-mercaptoethanol.

9. $50 \times$ hypoxanthine-aminopterin-thymidine (HAT)-media supplement.

10. $50 \%$ polyethylene glycol (PEG).

11. Cell storage solution: $85 \%$ FBS, $15 \%$ dimethyl sulfoxide (DMSO).

\subsection{Chemiluminescence Immunoassay}

1. Antigens.

a. Malondialdehyde acetaldehyde modified low density lipoprotein (MAA-LDL).

b. Malondialdehyde modified low density lipoprotein (MDA-LDL).

c. Copper oxidized LDL (CuOx-LDL).

d. Native LDL. 
e. Bovine serum albumin (BSA).

f. Malondialdehyde acetaldehyde modified bovine serum albumin (MAA-BSA).

g. Malondialdehyde modified bovine serum albumin (MDA-BSA).

h. Oxidized phosphatidylcholine bovine serum albumin (PC-BSA).

i. Cell wall polysaccharide (CWPS).

j. $\quad 0.5 \%$ fish gelatin-PBS (FG-PBS): .

k. A. actinomycetemcomitans serotypes $a, b, c, d, e, f, x$.

l. E. coli and S. pyogenes.

m. Recombinant $A a$ chaperonin 60.

2. PBS-EDTA buffer: $1 \times$ PBS with 0.27 mM EDTA.

3. FG-PBS-EDTA buffer: $0.5 \%$ FG in $1 \times$ PBS with $0.27 \mathrm{mM}$ EDTA.

4. Alkaline phosphatase-conjugated anti-mouse IgM.

5. Nunc Microfluor2 96-well plates.

6. An automated plate washer.

7. LumiPhos 530 (33\%) (Lumigen).

8. A Wallac Victor3 multilabel counter.

\subsection{Production and Purification of Antibody}

1. Serum-free HyClone ${ }^{\mathrm{TM}}$ SFM4MAb-Utility Medium.

2. Amicon Ultra-15 Centrifugal Filter Units (MWCO $100 \mathrm{kDa}$ ).

3. Superose 6 10/30 GL high-performance size exclusion chromatography columns and ÄKTAexplorer.

4. $10 \%$ sodium dodecyl sulfate (SDS) polyacrylamide gel.

5. Precision Plus Protein ${ }^{\mathrm{TM}}$ All Blue Prestained Protein Standards. 
6. PageBlue ${ }^{\mathrm{TM}}$ Protein Staining Solution.

\subsection{Total RNA Isolation, cDNA Amplification, Sequence Analysis}

1. RNeasy Mini Kit.

2. RevertAid First Strand cDNA Synthesis Kit.

3. IgM heavy pair primers: forward (MH1) 5'-SARGTNMAGCTGSAGSAGTC-3', reverse (IgM) 5'-GACATTTGGGAAGGACTGACTCTC-3'.

4. IgM light pair primers: forward (5MK) 5'-GAYATTGTGMTSACMCARWCTMCA-3', reverse (3KC) 5'-GGATACAGTTGGTGCAGCATC-3'.

5. dNTPs.

6. AmpliTaq polymerase.

7. Nuclease-free $\mathrm{H}_{2} \mathrm{O}$.

8. Thermo cycler PCR equipment.

9. $1.2 \%$ agarose gel.

10. ChemiDoc XRS Gel Imaging System.

11. Quantity One software.

12. GeneJET PCR purification kit.

13. ABI3500xL Genetic Analyzer.

\subsection{Mass Spectrometry}

1. $10 \%$ SDS polyacrylamide gel.

2. Precision Plus Protein ${ }^{\mathrm{TM}}$ All Blue Prestained Protein Standards.

3. PageBlue ${ }^{\mathrm{TM}}$ Protein Staining Solution.

4. SDS-PAGE washing buffer: $40 \%$ acetonitrile, $60 \%$ water, $50 \mathrm{mM}$ ammoniumbicarbonate.

5. Dithiothreitol (DTT) buffer: SDS-PAGE washing buffer, 20 mM DTT. 
6. Iodoacetamide.

7. Trypsin buffer: $9 \%$ acetonitrile, $91 \%$ water, $40 \mathrm{mM}$ ammoniumbicarbontae.

8. Trypsin solution: $20 \mathrm{ng} / \mu \mathrm{L}$ trypsin in trypsin buffer.

9. 800-384 anchor chip plate.

10. $\alpha$-Cyano-4-hydroxycinnamic acid (MALDI matrix).

11. UltrafleXtreme MALDI Tof Tof instrument.

12. MASCOT software from Matrix science.

\subsection{Expression and Purification of Aa Chaperonin 60}

1. Aa chaperonin $60 \mathrm{cDNA}$ in pET28a(+) expression vector (GenScript).

2. Competent BL21(DE3) E. coli cells.

3. SOB broths: $2 \%$ tryptone, $0.5 \%$ yeast extract, $8.56 \mathrm{mM} \mathrm{NaCl}, 2.5 \mathrm{mM} \mathrm{KCl}, 20 \mathrm{mM} \mathrm{MgCl}$.

4. SOC broths: SOB broth, $20 \mathrm{mM}$ glucose.

5. LB broths: $1 \%$ tryptone, $0.5 \%$ yeast extract, $1 \% \mathrm{NaCl}$.

6. LB kanamycin (LBK) plates: LB containing $30 \mu \mathrm{g} / \mathrm{mL}$ of kanamycin.

7. $0.5 \mathrm{M}$ isopropyl $\beta$-D-1-thiogalactopyranoside (IPTG).

8. Lysozyme $(50 \mathrm{mg} / \mathrm{mL})$.

9. $1 \mathrm{M} \mathrm{MgCl}_{2}$.

10. $1 \mathrm{M} \mathrm{CaCl}_{2}$.

11. SIGMAFAST ${ }^{\mathrm{TM}}$ Protease Inhibitor Tablets, EDTA-Free.

12. Recombinant DNase I (RNase-free, $10 \mathrm{U} / \mu \mathrm{L})$.

13. Digital Sonifier ${ }^{\circledR}$ Cell Disruptor.

14. Ultracentrifuge Beckman Optima L-100K.

15. HisPur ${ }^{\mathrm{TM}}$ Cobalt resin.

16. $3 \mathrm{M}$ imidazole. 
17. 50mM sodium phosphate buffer, $\mathrm{pH} 7.4: 4.23 \mathrm{ml}$ of $1 \mathrm{M} \mathrm{NaH}_{2} \mathrm{PO}_{4}(\mathrm{pH} 7.4$ adjusted by 10 $\mathrm{M} \mathrm{NaOH}$ ), $5.77 \mathrm{ml}$ of $1 \mathrm{M} \mathrm{Na}_{2} \mathrm{HPO}_{4}\left(\mathrm{pH} 7.4\right.$ adjusted by $37 \% \mathrm{HCl}$ ), $190 \mathrm{ml}$ of $\mathrm{H}_{2} \mathrm{O}$

18. Binding buffer: $300 \mathrm{mM} \mathrm{NaCl}, 50 \mathrm{mM}$ sodium phosphate buffer, $\mathrm{pH} 7.4$.

19. Washing buffer: $20 \mathrm{mM}$ imidazole in binding buffer.

20. Elution buffer: $150 \mathrm{mM}$ imidazole in binding buffer.

21. Amicon Ultra-15 Centrifugal Filter Units (MWCO 10 kDa).

22. 7 kDa MWCO Zeba Desalt Spin Column.

\subsection{Dot Blot and Western Blot}

1. Bio-Dot ${ }^{\circledR}$ microfiltration apparatus.

2. Nitrocellulose membrane.

3. Tris buffered saline (TBS): $20 \mathrm{mM}$ Tris-HCl, $\mathrm{pH} 7.5,150 \mathrm{mM} \mathrm{NaCl}$.

4. Blocking buffer: TBS, $5 \%$ BSA.

5. Antibody buffer: TBS, $5 \%$ BSA, $0.05 \%$ Tween 20 .

6. Washing buffer: TBS, $0.05 \%$ Tween 20.

7. Goat-anti-mouse IgM IRDye $800 \mathrm{CW}(0.5 \mu \mathrm{g} / \mathrm{mL})$.

8. Alexa Fluor 680 goat-anti-mouse $\operatorname{IgM}(0.5 \mu \mathrm{g} / \mathrm{mL})$.

9. Odyssey Infrared imager and Image Studio ${ }^{\mathrm{TM}}$ Software.

\section{Methods}

\subsection{Bacterial Cultivation}

1. Grow A. actinomycetemcomitans serotypes $(a, b, c, d, e, f, x), E$. coli and $S$. pyogenes are on FAA plates at $37{ }^{\circ} \mathrm{C}$ with $5 \% \mathrm{CO}_{2}$ for 2 days (see Note $\mathbf{1}$ ).

2. Pick bacterial cells from the plates and suspend in $1 \times$ PBS without heat inactivation.

3. Measure protein concentrations by $D C^{\mathrm{TM}}$ (detergent compatible) protein assay kit. 


\subsection{Cloning of Mouse Monoclonal IgM}

1. Generate hybridoma cells by fusion of splenocytes from a non-immunized nrf $2^{-/-}$mouse with P3×63Ag8.653.1 myeloma cells using standard polyethylene glycol method [21] followed by selection in $1 \times$ HAT medium for a following 2 week period (see Note 2 ).

2. Grow the cells at $37{ }^{\circ} \mathrm{C}$ with $5 \% \mathrm{CO}_{2}$ in $20 \%$ FBS-DMEM. Collect and screen the culture medium (see Note 3).

3. Apply chemiluminescence immunoassay [10] to select IgM secreting hybridoma cells to MAA-LDL (see Note 4). Immobilize MAA-LDL $(5 \mu \mathrm{g} / \mathrm{mL})$ overnight at $4{ }^{\circ} \mathrm{C}$ to Nunc Microfluor2 96-well plates in $1 \times$ PBS. Block nonspecific binding sites with $50 \mu \mathrm{L}$ of FGPBS-EDTA buffer. Add hybridoma culture medium $(25$ - $50 \mu \mathrm{L}$, see Note 5) and incubate at room temperature for 1 hour. Use the same volume of alkaline phosphatase-conjugated anti-mouse $\operatorname{IgM}(1: 30000)$ as a secondary antibody and $25 \mu \mathrm{L}$ of LumiPhos $530(33 \%)$ as substrate in the assay. Measure the chemiluminescence as relative light units (RLU) with a Wallac Victor3 multilabel counter.

4. Establish monoclonal hybridoma cell lines by limiting dilution from IgM producing cells. Propagate the selected clones and store in a cell storage solution in liquid nitrogen

\subsection{Production and Purification of Mouse Monoclonal Antibody to MAA-LDL}

1. Aa_Mab (clone HMN-08_34) is selected to grow and expand it in DMEM containing 10\% FBS at $37{ }^{\circ} \mathrm{C}$ with $5 \% \mathrm{CO}_{2}$ (see Note 6).

2. Following wash with PBS, transfer the cells to serum-free HyClone ${ }^{\mathrm{TM}}$ SFM4MAb-Utility medium and let to grow for 2 weeks.

3. Collect the medium and concentrate by Amicon Ultra-15 Centrifugal Filter Units (MWCO $100 \mathrm{kDa})($ see Note 7). 
4. Carry out the antibody purification using Superose 6 10/30 GL high-performance size exclusion chromatography columns with ÄKTAexplorer.

5. Verify purity of the antibody by running $10 \%$ SDS-polyacrylamide gel electrophoresis (PAGE) (see Note 8)

\subsection{Total RNA Isolation, cDNA Amplification, Sequence Analysis}

1. Grow the Aa_Mab (clone HMN-08_34) hybridoma cells in 35mm plates in DMEM containing $10 \% \mathrm{FBS}$ at $37{ }^{\circ} \mathrm{C}$ with $5 \% \mathrm{CO}_{2}$. Collect the cells following wash with PBS (see Note 9).

2. Isolate total RNA with RNeasy Mini Kit (see Note 10) and use this RNA to synthesize cDNA with RevertAid Reverse Transcriptase and oligo (dT) 18 primers included in the RevertAid First Strand cDNA Synthesis Kit (see Note 11).

3. Amplify the cDNA from reverse transcription by PCR using IgM heavy pair and IgM light pair primers [22]. The PCR reaction $(100 \mu \mathrm{L})$ contains $2 \mu \mathrm{L}$ of cDNA, $4 \mu \mathrm{L}$ each of of IgM primer $(5 \mu \mathrm{M}), 4 \mu \mathrm{L}$ of dNTPs $(2.5 \mathrm{mM}$ each $), 10 \mu \mathrm{L}$ of $10 \times$ PCR reaction buffer with $15 \mathrm{mM} \mathrm{MgCl}, 0.5 \mu \mathrm{L}$ of AmpliTaq polymerase $(5 \mathrm{U} / \mathrm{ml})$ and $75.5 \mu \mathrm{L}$ of nucleasefree $\mathrm{H}_{2} \mathrm{O}$. Run the PCR by using following program: $95^{\circ} \mathrm{C} \times 5 \mathrm{~min} ; 95^{\circ} \mathrm{C} \times 1 \mathrm{~min}, 45^{\circ} \mathrm{C}$ $\times 1 \mathrm{~min}, 72^{\circ} \mathrm{C} \times 2 \mathrm{~min}$ for 30 cycles; $72^{\circ} \mathrm{C} \times 10 \mathrm{~min} ; 10^{\circ} \mathrm{C} \times 1 \mathrm{~min} ; 4^{\circ} \mathrm{C} \times$ overnight.

4. Check the amplified PCR products by running $1.2 \%$ agarose gel electrophoresis and obtain the images by using ChemiDoc XRS Gel Imaging System and Quantity One software. Further purify the PCR products with GeneJET PCR purification kit and analyze the nucleotide sequences ABI3500xL Genetic Analyzer (see Note 12).

5. Align the antibody sequences to the germ-line genes with IMGT/V-QUEST sequence alignment tool (http://www.imgt.org).

\subsection{Mass Spectrometry Analysis}


1. Separate the bacterial protein recognized by Aa_Mab IgM by running $10 \%$ SDS-PAGE.

2. After being stained by Coomassie Brilliant Blue, cut the bands with correct size, destain with SDS-PAGE washing buffer, and reduce with DTT buffer for $30 \mathrm{~min}$ at room temperature.

3. Carry out alkylation by adding a stoichiometric amount of iodoacetamide. Incubate for 30 min, wash for 5 min once with SDS-PAGE washing buffer and twice with trypsin buffer.

4. Perform the sample digestion by first adding $5 \mu \mathrm{L}$ of trypsin solution to the gel pieces for 20 minutes. Then add $15 \mu \mathrm{L}$ of trypsin buffer and keep incubated at $35^{\circ} \mathrm{C}$ overnight.

5. Dry $0.5 \mu \mathrm{L}$ of the supernatant on an 800-384 anchor chip plate and dry a solution of $\alpha$ Cyano-4-hydroxycinnamic acid as MALDI matrix on top of the sample.

6. Measure the mass spectra on an UltrafleXtreme MALDI Tof Tof instrument with an automated method by first acquiring peptide fingerprint data in reflectron mode between m/z 700 and 4000, after which automatically select up to 10 ions for MS/MS interrogation. Externally calibrate the spectra with peptide calibration mixture.

7. Combine the fingerprint and MS/MS data and subject to search in the NCBI non redundant database with MASCOT using the following parameters: No species restriction, carbamidomethylation of cysteins as global modification, optional methionine oxidation, $20 \mathrm{ppm}$ mass tolerance for peptide masses and 0.7 Da for MS/MS fragments.

\subsection{Expression and Purification of Recombinant Aa Chaperonin 60}

1. Thaw on ice competent $B L 21(D E 3)$ E. coli cells from $-80{ }^{\circ} \mathrm{C}$ and add $100 \mu \mathrm{L}$ into a prechilled $14 \mathrm{~mL}$ polypropylene tube. Add $\beta$-mercaptoethanol to a final concentration of $25 \mathrm{mM}$. Incubate the reactions on ice for $10 \mathrm{~min}$, swirling gently every $2 \mathrm{~min}$.

2. Add $1 \mathrm{ng}$ of the $A a$ chaperonin 60 cDNA in pET28a(+) expression vector to the transformation tube and incubate on ice for $30 \mathrm{~min}$.

3. Then, heat in a $42{ }^{\circ} \mathrm{C}$ water bath for 45 seconds and incubate on ice for 2 min. 
4. Add $0.9 \mathrm{~mL}$ of preheated $\left(42^{\circ} \mathrm{C}\right) \mathrm{SOC}$ medium to the transformation reaction and incubate at $37{ }^{\circ} \mathrm{C}$ for 1 hour with shaking at $250 \mathrm{rpm}$.

5. Spread $100 \mu \mathrm{L}$ of the cells onto LBK agar plates and grow at $37^{\circ} \mathrm{C}$ overnight (see Note 13).

6. Pick up a single colony and grow in $50 \mathrm{~mL}$ of $\mathrm{LB}$ broth containing kanamycin $(30 \mu \mathrm{g} / \mathrm{ml})$ at $37^{\circ} \mathrm{C}$ with vigorous shaking $(220 \mathrm{rpm})$ for $16-20$ hours.

7. Dilute the bacterial culture to 2 liters by LB broth containing kanamycin.

8. Induce the protein expression $30^{\circ} \mathrm{C}$ for 18 hours by adding $1 \mathrm{mM}$ of IPTG when $\mathrm{OD}_{600}$ reaches $0.6-0.8$.

9. Pellet the bacterial cells $\left(3,000 \times \mathrm{g}\right.$ for $30 \mathrm{~min}$ at $\left.4{ }^{\circ} \mathrm{C}\right)$, resuspend and lyse in binding buffer, supplement with proteinase inhibitor and lysozyme $(1 \mathrm{mg} / \mathrm{mL})$ at $37^{\circ} \mathrm{C}$ for 1 hour.

10. Add DNase I (4U/mL), $\mathrm{MgCl}_{2}(2.5 \mathrm{mM})$ and $\mathrm{CaCl}_{2}(0.1 \mathrm{mM})$ and incubate for further 1 hour.

11. Finally lyse the cells with sonication by Digital Sonifier® Cell Disruptor. Pellet the cells debris by ultracentrifugation at $48,000 \times \mathrm{g}$ for 30 minutes at $4^{\circ} \mathrm{C}$.

12. Collect the crude cell lysates and save at $4^{\circ} \mathrm{C}$.

13. Carryout the protein purification by using HisPur ${ }^{\mathrm{TM}}$ Cobalt resin. The binding is done by rotating the mix of cell lysates and resin at $4{ }^{\circ} \mathrm{C}$ overnight in binding buffer. Add imidazole to the buffer for washing $(20 \mathrm{mM})$ and for elution $(150 \mathrm{mM})$ respectively.

14. Deslat the eluted Aa chaperonin 60 by 7 kDa MWCO Zeba Desalt Spin Column with PBS (see Note 14).

\subsection{Chemiluminescence Immunoassay With Aa_Mab Antibody}

1. To investigate the direct binding characteristics of the monoclonal $\operatorname{IgM}$ antibody (Aa_Mab), immobilize various amounts $(0-100 \mu \mathrm{g} / \mathrm{mL})$ of antigens overnight at $4^{\circ} \mathrm{C}$ to 
Nunc Microfluor2 96-well plates in PBS. The antigens are MAA-LDL, MDA-LDL, CuOx-LDL, native LDL, MAA-BSA, MDA-BSA, PC-BSA, BSA, CWPS, FG-PBS, seven serotypes $(a, b, c, d, e, f, x)$ of A. actinomycetemcomitans, E. coli, S.pyogenes and recombinant $A a$ chaperonin 60.

2. Wash the wells three times with PBS-EDTA buffer by an automated plate washer between each step of the immunoassays. Block the nonspecific binding sites with FG-PBS- EDTA buffer for 1 hour at room temperature.

3. Add Aa_Mab $(1-2.5 \mu \mathrm{g} / \mathrm{mL})$ to incubate at room temperature for 1 hour. Use $50 \mu \mathrm{L}$ of alkaline phosphatase-conjugated anti-mouse $\operatorname{IgM}(1: 30000)$ as a secondary antibody and $25 \mu \mathrm{L}$ of LumiPhos 530 (33\%) as a substrate in the assay.

4. Measure the chemiluminescence as RLU with a Wallac Victor3 multilabel counter (see Note 15).

5. In competitive immunoassay, incubate Aa_Mab antibody $(0.125-0.25 \mu \mathrm{g} / \mathrm{mL})$ with either soluble antigens (MAA-LDL, MDA-LDL, CuOx-LDL, Native LDL, MAA-BSA, MDABSA, PC-BSA, BSA, CWPS, FG-PBS) or bacteria $(7$ serotypes of $A$. actinomycetemcomitans, E. coli and $S$. pyogenes) as competitors with concentrations at 0 - $100 \mu \mathrm{g} / \mathrm{mL}$ overnight at $4{ }^{\circ} \mathrm{C}$. Centrifuge the samples at $16000 \times \mathrm{g}$ for $30 \mathrm{~min}$ at $4{ }^{\circ} \mathrm{C}$ before adding to microtiter plates with immobilized MAA-LDL $(5 \mu \mathrm{g} / \mathrm{mL})$ or $A a$ chaperonin $60(5 \mu \mathrm{g} / \mathrm{mL})$. Complete the rest of the assay as in direct binding analysis (steps 1-4).

\subsection{Dot Blot and Western Blot Analysis}

1. For dot blot, load bacterial suspension $(10 \mu \mathrm{g}$ protein/strain/well) in $200 \mu \mathrm{L}$ of $\mathrm{TBS}$, by vacuum for 1 hour at room temperature onto pre-wet nitrocellulose membrane using Bio$\operatorname{Dot}^{\circledR}$ microfiltration apparatus (see Note 16). 
2. For western blot, first separate the bacterial suspension (17 $\mu \mathrm{g}$ protein/strain/lane) by running $10 \%$ SDS-PAGE and then blott onto nitrocellulose membranes under $30 \mathrm{~V}$ at $4{ }^{\circ} \mathrm{C}$ overnight (see Note 17).

3. Block all blots in blocking buffer for 1 hour at room temperature, incubate with Aa_Mab antibody $(2.5 \mu \mathrm{g} / \mathrm{mL}$ for dot blot and $1 \mu \mathrm{g} / \mathrm{mL}$ for western blot) in 5antibody buffer for 1 hour at room temperature.

4. Wash the blots by washing buffer for $5-10 \mathrm{~min}$ at room temperature for three times (see Note 18).

5. Visualize the binding of Aa_Mab to bacterial proteins by incubating further with goat-antimouse IgM IRDye800CW $(0.5 \mu \mathrm{g} / \mathrm{mL})$ for 1 hour at room temperature (see Note $\mathbf{1 8})$.

6. Measure the fluorescent signals with an Odyssey IR imager and Image Studio ${ }^{\mathrm{TM}}$ Software.

7. For western blot analysis of recombinant $A a$ chaperonin 60 , load $2 \mu \mathrm{g}$ of proteins ( $A a$ chaperonin 60, MAA-BSA, and BSA, respectively) per lane. Use Aa_Mab $(0.1 \mu \mathrm{g} / \mathrm{mL})$ as primary antibody, and Alexa Fluor 680 goat-anti-mouse $\operatorname{IgM}(0.5 \mu \mathrm{g} / \mathrm{mL})$ as secondary antibody (see Note 19).

\section{Notes}

1. Purity of the bacterial cultures can be checked by colony morphology and gram-staining.

2. The $1 \times$ HAT selection medium is diluted from $50 \times$ HAT by $20 \%$ FBS-DMEM. The HAT selection medium needs to be made freshly and changed every day for about two weeks until hybridoma clones are clearly visible.

3. The hybridoma culture media are screened freshly or stored at $-20{ }^{\circ} \mathrm{C}$ temporarily for later use. 
4. Otherwise specified, all procedures are carried out at room temperature for 1 hour. All wells should be washed with an automated plate washer with PBS-EDTA buffer three times between each step of the immunoassays.

5. Either $25 \mu \mathrm{L}$ or $50 \mu \mathrm{L}$ of hybridoma culture media are used for chemiluminescence immunoassay depending on the volume of culture media in selection wells.

6. We allow the hybridoma cells to grow to reach a very high density because the more cells there are, the more antibodies they will produce.

7. The media are concentrated for about 200 times by centrifugation at $3,200 \times \mathrm{g}, 4^{\circ} \mathrm{C}$.

8. SDS gels are usually run at $200 \mathrm{~V}$ for 1 hour. The gels are washed by water for $3 \times 10$ minutes, stained in PageBlue ${ }^{\mathrm{TM}}$ Protein Staining Solution for 1 hour, and destained with several changes of water.

9. The cells should be freezed at $-80^{\circ} \mathrm{C}$ if they are not used straight for total RNA isolation. However, the RNA yield from fresh cells is much higher than the one from freezed cells.

10. Total RNA is extracted according to the manufacturer's instruction from $1 \times 10^{5}-1 \times 10^{7}$ cells with $\mathrm{A}_{260 / 280}$ ratios of $1.9-2.1$ and stored at $-80^{\circ} \mathrm{C}$.

11. The cDNA amplification is carried out according to the manufacturer's instruction and stored at $-20^{\circ} \mathrm{C}$.

12. The total volume of each PCR reaction is $100 \mu \mathrm{L}$ and only $10 \mu \mathrm{L}$ is used for agarose gel running ( $80 \mathrm{~V}$ for 1 hour). The rest samples $(90 \mu \mathrm{L})$ with successfully amplified PCR products are purified further for sequencing. The sequencing primers are $\mathrm{MH} 1$ or $\operatorname{IgM}$ for heavy chain and $5 \mathrm{MK}$ or $3 \mathrm{KC}$ for light chain.

13. The transformation is carried out according to the instructions from the competent cells supplier.

14. The binding of His-tagged proteins to Cobalt resin can also be done at room temperature for 1 hour. The washing steps are usually repeated three times by spinning down the 
bounded resin at 3,200 $\times \mathrm{g}$ for 2 minutes and discarding the unbounded supernatant. The elution is repeated three times, all eluates are combined and concentrated by Amicon Ultra15 Centrifugal Filter Units (MWCO $10 \mathrm{kDa}$ ). The desalting procedures are carried out according to the manufacturer's instruction.

15. The chemiluminescence immunoassay is basically carried out as the same as in section 3.2. Cloning of Mouse Monoclonal IgM except different antigens are immobilized overnight at $4^{\circ} \mathrm{C}$ to Nunc Microfluor2 96-well plates in PBS.

16. MAA-BSA and PC-BSA ( $2 \mu \mathrm{g} /$ well) are loaded as controls for dot blot assay.

17. MAA-BSA and BSA ( $2 \mu \mathrm{g} / \mathrm{lane})$ are taken as controls for western blot analysis.

18. All procedures are carried out with shaking.

19. The proteins are separated by $10 \%$ SDS-PAGE, blotted to nitrocellulose membrane, incubated with Aa_Mab and secondary antibody, and visualized under the same conditions as used in bacterial dot blot and western blot.

\section{Acknowledgement}

This study was funded by Sigrid Juselius Foundation and Finnish Foundation for Cardiovascular Research.

\section{References}

1. Grönwall C, Vas J, Silverman GJ (2012) Protective Roles of Natural IgM Antibodies. Front Immunol 3:66. 10.3389/fimmu.2012.00066

2. Panda S, Zhang J, Tan NS, Ho B, Ding JL (2013) Natural IgG antibodies provide innate protection against ficolin-opsonized bacteria. EMBO J 32(22):2905-2919.

10.1038/emboj.2013.199 [doi]

3. Pabst O (2012) New concepts in the generation and functions of IgA. Nat Rev Immunol 12(12):821-832. 10.1038/nri3322 [doi] 
4. Tsiantoulas D, Diehl CJ, Witztum JL, Binder C (2014) B cells and humoral immunity in atherosclerosis. Circ Res 114(11):1743-1756. 10.1161/CIRCRESAHA.113.301145 [doi]

5. Grönwall C, Silverman GJ (2014) Natural IgM: Beneficial Autoantibodies for the Control of Inflammatory and Autoimmune Disease. J Clin Immunol 34 Suppl 1:12-21. 10.1007/s 10875-014-0025-4 [doi]

6. Lewis MJ, Malik TH, Ehrenstein MR, Boyle JJ, Botto M, Haskard DO (2009) Immunoglobulin $\mathrm{M}$ is required for protection against atherosclerosis in low-density lipoprotein receptor-deficient mice. Circulation 120(5):417-426.

10.1161/CIRCULATIONAHA.109.868158

7. Kyaw T, Tay C, Krishnamurthi S, Kanellakis P, Agrotis A, Tipping P et al (2011) B1a B lymphocytes are atheroprotective by secreting natural IgM that increases IgM deposits and reduces necrotic cores in atherosclerotic lesions. Circ Res 109(8):830-840.

10.1161/CIRCRESAHA.111.248542 [doi]

8. Karvonen J, Päivänsalo M, Kesäniemi YA, Hörkkö S (2003) Immunoglobulin M type of autoantibodies to oxidized low-density lipoprotein has an inverse relation to carotid artery atherosclerosis. Circulation 108(17):2107-2112. 10.1161/01.CIR.0000092891.55157.A7

9. Tsimikas S, Miyanohara A, Hartvigsen K, Merki E, Shaw PX, Chou MY et al (2011) Human oxidation-specific antibodies reduce foam cell formation and atherosclerosis progression. J Am Coll Cardiol 58(16):1715-1727. 10.1016/j.jacc.2011.07.017

10. Wang C, Turunen SP, Kummu O, Veneskoski M, Lehtimäki J, Nissinen AE et al (2013) Natural antibodies of newborns recognize oxidative stress-related malondialdehyde acetaldehyde adducts on apoptotic cells and atherosclerotic plaques. Int Immunol 25(10):575-587. 10.1093/intimm/dxt022 [doi]

11. Turunen SP, Kummu O, Harila K, Veneskoski M, Soliymani R, Baumann M et al (2012) Recognition of Porphyromonas gingivalis gingipain epitopes by natural IgM binding to malondialdehyde modified low-density lipoprotein. PLoS One 7(4):e34910.

10.1371/journal.pone.0034910 [doi]

12. Wang C, Kankaanpää J, Kummu O, Turunen SP, Akhi R, Bergmann U et al (2016) Characterization of a natural mouse monoclonal antibody recognizing epitopes shared by oxidized low-density lipoprotein and chaperonin 60 of Aggregatibacter actinomycetemcomitans. Immunol Res. 10.1007/s12026-015-8781-7 [doi]

13. Demmer RT, Desvarieux M (2006) Periodontal infections and cardiovascular disease: the heart of the matter. J Am Dent Assoc 137 Suppl:14S-20S; quiz 38S. 137/suppl_2/14S [pii]

14. Lockhart PB, Bolger AF, Papapanou PN, Osinbowale O, Trevisan M, Levison ME, et al (2012) Periodontal disease and atherosclerotic vascular disease: does the evidence support an independent association?: a scientific statement from the American Heart Association. Circulation 125(20):2520-2544. 10.1161/CIR.0b013e31825719f3 [doi] 
15. Pussinen PJ, Jousilahti P, Alfthan G, Palosuo T, Asikainen S, Salomaa V. (2003) Antibodies to periodontal pathogens are associated with coronary heart disease. Arterioscler Thromb Vasc Biol 23(7):1250-1254. 10.1161/01.ATV.0000072969.71452.87 [doi]

16. Hyvärinen K, Mäntylä P, Buhlin K, Paju S, Nieminen MS, Sinisalo J et al (2012) A common periodontal pathogen has an adverse association with both acute and stable coronary artery disease. Atherosclerosis 223(2):478-484.

10.1016/j.atherosclerosis.2012.05.021 [doi]

17. Calandrini CA, Ribeiro AC, Gonnelli AC, Ota-Tsuzuki C, Rangel LP, Saba-Chujfi E, et al (2014) Microbial composition of atherosclerotic plaques. Oral Dis 20(3):e128-34. 10.1111/odi.12205 [doi]

18. Buhlin K, Holmer J, Gustafsson A, Hörkkö S, Pockley AG, Johansson A et al (2015) Association of periodontitis with persistent, pro-atherogenic antibody responses. J Clin Periodontol. 10.1111/jcpe.12456 [doi]

19. Turunen SP, Kummu O, Wang C, Harila K, Mattila R, Sahlman M et al (2015) Immunization with malondialdehyde-modified low-density lipoprotein (LDL) reduces atherosclerosis in LDL receptor-deficient mice challenged with Porphyromonas gingivalis. Innate Immun 21(4):370-385. 10.1177/1753425914542444 [doi]

20. Pussinen PJ, Vilkuna-Rautiainen T, Alfthan G Mattila K, Asikainen S (2002) Multiserotype enzyme-linked immunosorbent assay as a diagnostic aid for periodontitis in large-scale studies. J Clin Microbiol 40(2):512-518

21. Greenfield EA (2014) Generating monoclonal antibodies. In: Greenfield EA (ed) Antibodies: A Laboratory Manual, 2nd edn. Cold Spring Harbor Laboratory Press, New York, pp 201-221

22. Wang Z, Raifu M, Howard M, Smith L, Hansen D, Goldsby R et al (2000) Universal PCR amplification of mouse immunoglobulin gene variable regions: the design of degenerate primers and an assessment of the effect of DNA polymerase 3 ' to 5' exonuclease activity. J Immunol Methods 233(1-2):167-177. S0022175999001842 [pii] 